\title{
Motivation, Psychology and Language Effect on Mobile Learning in Universiti Sains Malaysia
}

\author{
$\underline{\text { doi:10.3991/ijim.v4i4.1408 }}$
}

\author{
Issham Ismail, Rozhan M. Idrus and Thenmolli Gunasegaran \\ Universiti Sains Malaysia, Penang, Malaysia
}

\begin{abstract}
The aim of this study was to examine the motivation, psychology and language effect on Mobile learning in the School of Distance Education, Universiti Sains Malaysia, Penang. Mobile learning or m-learning is a new learning phenomenon in the open and distance learning environments. Moving from stationary to mobile learning allows informal collaboration and interaction between learners. Therefore, there is a necessity to revise people's psychological factors, process and mechanisms that underlie $M$ learning so that the practice can move from technologycentred implementation to human-centred effective learning processes. The Statistical Package for Social Science (SPSS) Version 12.0 and Rasch Model Analysis was used to measure these items. The 5-point Likert scale questionnaires (12 items) being sent to 105 distance education students from four courses including Bachelor of Science, Bachelor of Arts, Bachelor of Social Science and Bachelor of Management which was distributed in tutorial sessions during the annual residential intensive course in the main campus of the Universiti Sains Malaysia by their respective course managers. The finding shows that a positive response from the learners as they feel happy to use this additional learning tools (mobile learning). Learner's feel supported and motivated to use the mobile application with the usability of simple language.
\end{abstract}

Index Terms-Mobile Learning, Motivation, Psychology, SMS Language.

\section{INTRODUCTION}

The development of ICT education in Malaysia is in line aspiration of the country to move toward the status of a developed nation by 2020, hereafter referred as 'Wawasan 2020' (Vision 2020), aimed at establishing Malaysia to achieve sustainable growth for the nation. In order to achieve this vision the education system need to be transformed. Technology is seen as the core source in developing new media as tools in enhancing the pedagogies and enriching the curriculum. Electronic or e-learning is being used widely in the open and distance education programmes in delivering teaching and learning via electronic media. E-learning integrates all forms of online instructions using electronic devices. Mobile learning or commonly known as m-learning is a specialised form of elearning [1].

A mobile or hand phone is a portable electronic device for mobile communication. Recent mobile phones which is in addition to the standard voice function of a telephone, can support many additional services such as SMS (Short Message Service) for text messaging, e-mail, packet switching for access to the Internet, MMS (Multimedia Messaging Service) for sending and receiving images, rich text, audio, photos and video and EMS (Enhanced Mes- saging Services) which allows users to integrate text, audio, pictures, video and animation.

Mobile learning become a new learning experience in the open and distance learning environments [2]. Quinn gives definition of mobile learning as learning through mobile computational devices [3] while another definition is by which defined mobile learning as a field which synchronize two capable fields - mobile computing and Elearning [4]. M-learning is a distinctive way of leaning as learners can access the course material, instructions and other content related applications anytime and anywhere [5]. This is found to be increasing daily attention to learning material, makes learning pervasive and also boosts the learner's motivation for lifelong learning. Moving from stationary to mobile learning allows informal collaboration and interaction between learners.

As reported by Malaysian Communications and Multimedia Commission (MCMC) in Quarter 2, 2009, the penetration rate for cellular phone in Malaysia is $100.8 \%$ whereby the penetration rate over $100 \%$ occurs because of multiple subscriptions [6]. A mobile phone is a multipurpose device which provides a number of functions and services not only limited to transmitting voice communication but also the short messaging service is one of it. There are few factors that affect the adoption of SMS as previous studies illustrates the ways in which everyday life activities influence mobile phone use and to a certain extent SMS usage [7] [8]. As a result, this study was undertaken aligned with the vast usage of mobile phone for educational purposes mainly for the distance learners of Universiti Sains Malaysia. The users namely the learners and the lecturers will be receiving and sending contents through mobile phones using a basic feature which is SMS.

Study done illustrated that students benefited from the advantages of the offered features of mobile communication where they can check timetable, class delay and current updates using their own mobile phones [9]. This indicates that mobile phones are virtually a requirement to keep up with the demands of everyday life. Increasingly, advancements in these mobile devices are making them even more practical not only for on-the-go communication, but also for on-demand information sharing, training and learning.

A study from University of Pretoria in South Africa shows that there were none of the post-graduate students in the open-education program had email or could avail of e-Learning but all had mobile phones, the university used mobile phones very successfully to administrate their paper-based distance education programs, achieving almost immediate communication by text messaging [10]. Nevertheless there are factors that affect the intention to adopt 


\section{Motivation, Psychology And Language EfFect On Mobile Learning IN UNIVERSITI SAINS MALAYSIA}

a new learning tool and it is due to the difference in learners motivation or instructional characteristics [11] [12].

Researcher revealed that motivation is a vital factor in instruction and it is apparent that high motivation will enhance attention and consequently lead to learning success [13]. While another study indicated this assumption does not have to be the case because "good feelings" during learning sessions are not necessarily an indicator for effective learning [14]. It did not seem to be reasonable to assume that multimedia motivates learners per se [15]. However Schulmeister pointed out that users found the presentation of new media interesting and stimulating [16]. This Hawthorne effect has to be taken into account while evaluating e-learning software because it diminishes after a certain use of the software and might therefore lead the researchers to false conclusions during the initial phase of the evaluation. Technology used in learning therefore can provide a variety of value in several ways but depending how the learners perceive and benefit from it.

The psychology effect of using mobile learning is an important aspect to be explored as it resembles the feeling of the learners when they receive the learning content. The acceptance of SMS-Learning depends on the learners' satisfaction and usability of the system to cater their need and learning results. There will always and risk in accepting the system unless learners see the value in the technology to support access to important course information, to support learning and to provide more control over the learning process, they may be less likely to use the technology [17]. Learners should be informed well on the status of each message through a proper feedback within a time frame. A sufficient indication will explain the status and reduce learners' worries and frustration [18]. Research done noted that small screen with short lines will slow down the speed of reading by disrupting the usual pattern of eye movements which will circuitously distress human interaction [19]. Thus to have an effective system, both the parties the sender and the receiver should merely understand the messages delivered.

The messages send and receive serve to tie the group together through the development of a common history [20]. These messages are created on the tiny keypad of the phone and are limited to 160 characters in length [21]. Addition to it study merely done for distance learners indicates that learners prefer brief, short, concise messages are very useful in assisting them in revising subjects at anytime and anywhere [22]. This shows that the technical restrictions of text messaging have led to the development of language short forms in SMS communication e.g. limited space. Whilst the other reasons for short messages include the often difficult to manage interface and the fact that communications with close friends, partners and family members allows one to organize messages pragmatically as a common background exists. M-learning concerns how to improve people's learning with information technologies.

Hence, there is a necessity to revise learner's motivation, psychological factors, process and mechanisms that underlie M-learning so that the practice can move from technology-centred implementation to human-centred effective learning processes. This study is proposed to examine the motivation, psychology and language effect on Mobile learning in the School of Distance Education, Universiti Sains Malaysia.

\section{RESEARCH MEthodOLOGY}

Data received were analyzed using Statistical Package for Social Science (SPSS) Version 12.0, while for the Likert-type questions, the RASCH Measurement Model was used for analysis.

SPSS have been used for quantitative research and familiar among researchers. RASCH Model in the other hand is a one-parameter logistic model within item response theory (IRT) in which the amount of a given latent trait in a person and the amount of that same latent trait reflected in various items can be estimated independently yet still compared explicitly to one another.

\section{A. Instrument}

Questionnaire-based survey is used as the data collection instrument for this study. It includes eleven demographics questions and 154 Likert-type questions. A covering letter explaining the purpose of the questionnaire was also attached to the questionnaire.

The demographic questions capture information of the respondents regarding gender, age, ethnicity, marital status, year of study, study programme, current CGPA, mobile device ownership, working sector, course preferences, and salary range. The Likert-type questions are divided into two sections which are teaching and learning style and effectiveness of SMS learning.

The questions, captured information regarding students' perception, feelings, experiences and acceptance towards the implementation of mobile learning in distance education. Except for the questions on demographic information, all other questions used the five-point Likert Scale ranging from 1 to 5 , in which 1 was for 'strongly disagree', 2 was for 'disagree', 3 was for 'neutral', 4 was for 'agree' and 5 was for 'strongly agree'.

\section{B. Data Collection Procedure}

A total of 119 questionnaires were distributed to students from four different courses of the School of Distance Education, Universiti Sains Malaysia (USM) namely Bachelor of Science, Bachelor of Arts, Bachelor of Social Science and Bachelor of Management. A total of 105 questionnaires were returned hence making a response rate of 88 per cent. This high response rate could be due to the fact that the questionnaires were sent via email which was more convenient, faster and time saving.

USM's mobile learning assisted course was introduced in the second semester of the 2008/2009 academic session and covered two subjects of Bachelor Management namely Financial Principle of second year and International Business of third year.

On the other hand, for Bachelor of Science and in specific for Physics students, this mobile learning assisted course was used for Mechanics and Optics module of second year students. Bachelor Art covered the modules on Money and Banking of second year and Quantitative Economy of third year.

During the duration of the implementation of this mobile learning from February 2009 to April 2009, the registered students received text message once a day regarding their study modules. 


\section{Motivation, Psychology And Language EfFect On Mobile Learning \\ IN UNIVERSITI SAINS MALAYSIA}

\section{ANALYSIS AND FINDINGS}

\section{A. Demographic profile of respondents}

This section portrays respondents' demographic profile, such as gender, age, ethnicity, education streams as well as current CGPA. Female students took active part in this study. From the total of 105 respondents, 74 were females and 31 males. These findings truly aligned with Ling's conclusion in a study that although men were early adopters of mobile telephones yet it is among the women that the great motor of SMS lives [20].

Data in the table 1 shows that a majority of the respondents were Malay (60 students), followed by Chinese (27 students), Indian (11 students) and other ethnic group (7 students). There are 11 Indian and the rest which is 7 persons are from other ethnic group. According to the Malaysian Communication and Multimedia Commission in Malaysia, Malays contribute as the largest group of users of mobile phone and followed by Chinese, Indians and others [23].

As for the courses the respondents were from the Bachelor of Management (98 students). Followed by Bachelor of Science (2 students), Bachelor of Social Science ( 2 students) and the rest from Bachelor of Art (1 student).

Table 1 shows most respondents (96 students) have their own mobile phone. Lesser respondents (6 students) have both mobile phones and PDAs/pockets PCs/ palm tops devices and the least (3 students) have PDAs/pockets PCs/ palm tops.

\section{B. Reliability and Separation for Items in Variables}

In RASCH Measurement Model, the statistical summary tables of the learners and the items were produced to present an overall view of the reliability and validity of the instrument and the associated responses.

Reliability is the degree of measurements free from error and therefore yielding consistent results. Sekaran stated that, the closer the reliability coefficient (Cronbach's Alpha) to 1.0 the better it is and those values over .80 are consider as good [24]. While .70 is acceptable while below .60 is considered as poor. As illustrated in the related Table II, Cronbach's Alpha showed the value of .97. This indicates that the respondents were consistent in answering the questions asked. It also shows that most of the respondents saw the items being asked in same point of views as required by the questions.

\section{Reliability and Separation for Items in Variables}

In RASCH Measurement Model, the statistical summary tables of the learners and the items were produced to present an overall view of the reliability and validity of the instrument and the associated responses.

Reliability is the degree of measurements free from error and therefore yielding consistent results. As stated the closer the reliability coefficient (Cronbach's Alpha) to 1.0 the better it is and those values over .80 are consider as good [24]. While .70 is acceptable while below .60 is considered as poor. As illustrated in the related table, Cronbach's Alpha showed the value of .97. This indicates that the respondents were consistent in answering the questions asked. It also shows that most of the respondents saw the items being asked in same point of views as required by the questions.
TABLE I.

DEMOGRAPHIC DATA

\begin{tabular}{|l|l|c|}
\hline \multirow{3}{*}{ Gender } & Male & Frequency \\
& Female & 31 \\
Age & $20-29$ years & 74 \\
\hline \multirow{4}{*}{ Ethnicity } & $30-39$ years & 44 \\
& $40-49$ years & 46 \\
& 50 and above & 12 \\
& Malay & 3 \\
\hline \multirow{5}{*}{ Program } & Chinese & 60 \\
& Indian & 11 \\
& Others & 27 \\
& B. Science & 7 \\
\hline Mobile Device Own- & B. Arts & 2 \\
ership & Both phone & 2 \\
& B. Social Science & 98 \\
\hline & B. Management & 96 \\
& PDA/Pocket & 3 \\
\hline
\end{tabular}

TABLE II.

TEACHING AND LEARNING STYLE AND EFFECTIVENESS OF SMS LEARNING

\begin{tabular}{|c|c|c|c|}
\hline Item & Statement & $\begin{array}{c}\text { Infit } \\
\text { MNSQ }\end{array}$ & $\begin{array}{r}\text { Outfit } \\
\text { MNSQ }\end{array}$ \\
\hline S67 & $\begin{array}{l}\text { The assignment given by the lectur- } \\
\text { ers will help me to pass the final } \\
\text { exam }\end{array}$ & 1.42 & 1.35 \\
\hline S70 & $\begin{array}{l}\text { I prefer the way of lecture delivered } \\
\text { their teaching such as video confer- } \\
\text { encing, e-learning portal and inten- } \\
\text { sive classes held in this school }\end{array}$ & 1.28 & 1.35 \\
\hline S84 & $\begin{array}{l}\text { I found the intensive classes were } \\
\text { useful }\end{array}$ & 1.03 & 0.99 \\
\hline U143 & $\begin{array}{l}\text { Terminology is consistent with } \\
\text { general usage }\end{array}$ & 1.20 & 1.52 \\
\hline U140 & The language used is simple enough & 1.10 & 1.05 \\
\hline I126 & $\begin{array}{l}\text { I can conveniently contact and have } \\
\text { open communication with my in- } \\
\text { structor, teachers, and course } \\
\text { mates. }\end{array}$ & 1.16 & 1.20 \\
\hline SR150 & $\begin{array}{l}\text { Text messages from my lecturer } \\
\text { helped to motivate me to study }\end{array}$ & 0.82 & 0.82 \\
\hline S78 & $\begin{array}{l}\text { Lecturer encouraged student inter- } \\
\text { action in video conferencing and } \\
\text { portal }\end{array}$ & 0.80 & 0.78 \\
\hline I128 & $\begin{array}{l}\text { My instructors were available to } \\
\text { students }\end{array}$ & 1.12 & 1.15 \\
\hline I127 & $\begin{array}{l}\text { I receive responses from my in- } \\
\text { structors in a timely manner }\end{array}$ & 1.08 & 1.09 \\
\hline SR151 & $\begin{array}{l}\text { Text message from my lecturer } \\
\text { helped me to feel support by the } \\
\text { lecturer }\end{array}$ & 0.70 & 0.70 \\
\hline CP123 & $\begin{array}{l}\text { Course and technology used are } \\
\text { easy navigated consistent and easy } \\
\text { to use }\end{array}$ & 0.77 & 0.70 \\
\hline Mean & & 1.01 & 1.00 \\
\hline S.D. & & 0.18 & 0.20 \\
\hline
\end{tabular}

Cronbach alpha (KR-20) person raw score reliability $=.97$ 


\section{Motivation, Psychology And Language EfFect On Mobile Learning \\ IN UNIVERSITI SAINS MALAYSIA}

\section{Item/Person Misfit Order Table}

The item and person misfit value is also helpful in this study. The results represented the validation of the instrument whether it is suitable as a data collection tool [25]. Conversely, it was aimed to determine whether the instrument used is a valid tool to utilize for data collection. This can be achieved by checking the unidimensionity of the items. Outfit is the outside factors that influence the items or variables while infit represent the "off-variable noise" that could have impact on the items or variables.

According to Fox any item which falls within the infit and outfit limit of 0.6 to 1.5 is considered acceptable [26]. However, for Bond and Fox if the sample is less than 500 participants, the acceptable value of outfit range are from 0 to 1.3 [27].

Items that fall outside the acceptable range are considered to be invalid for the reason that the respondents viewed the items differently than that intended by the researcher [28. For this study, Table 2 measure the items of the variables fit the expectations of the RASCH Model. The data shows that infit mean-square fit statistics (MNSQs) is 1.01 while the outfit MNSQ is 1.0 which is a perfect result. Standard division (S.D.) is shown as 0.18 for infit MNSQ and 0.2 also represents that it is good since near and more than 0.2 .

In this study, the item statistics were used to evaluate every single item in the variables. However, statistics of the items being analyse, there are six items that fall outside the acceptable infit and outfit range, less than 0.6 and or greater than 1.5 as proposed by [26]. This may be due to the reason that the items did not fall into the fundamental construct or the respondents saw the items in different ways and interpreted them far from the way the researcher intended. Table 2, presents the data of other 24 items which are considered valid as they fall between the acceptable ranges of 0.6 to 1.5 .

\section{E. Variable Map}

Another visual guide to information regarding relative scales is the variable map [25]. Variable map is used to present the items by ranking them according to the level of difficulty to endorse as well as presenting the respondents by ranking them according to their willingness to endorse the items. The data of this study as shown in Figure 1 represents items that are ranked from the least favourite item or hardest to endorse at the top to the most favourite item (easiest to endorse) at the bottom. For the person analysis on the other hand, the respondents are ranked from top to bottom, from students who successfully transfer the learning to those who didn't transfer successfully or even not transferring at all.

\section{ANALYSIS AND FINDINGS}

The map in Figure 1, shows that students most easily endorse items Usability140, Student's Responsiveness150 and Student's Responsiveness 151 which represents the 'simplify language used", "text messages motivates the students in their studies"'. While it also concluded that ''they feel supported'. All these three items are classified under the effectiveness of SMS-Learning.

Item no. 151 (SR151) represented the learner's responsiveness towards the SMS-Learning system. The result showed that the learners strongly agreed that they felt supported when the lecturers used mobile application for

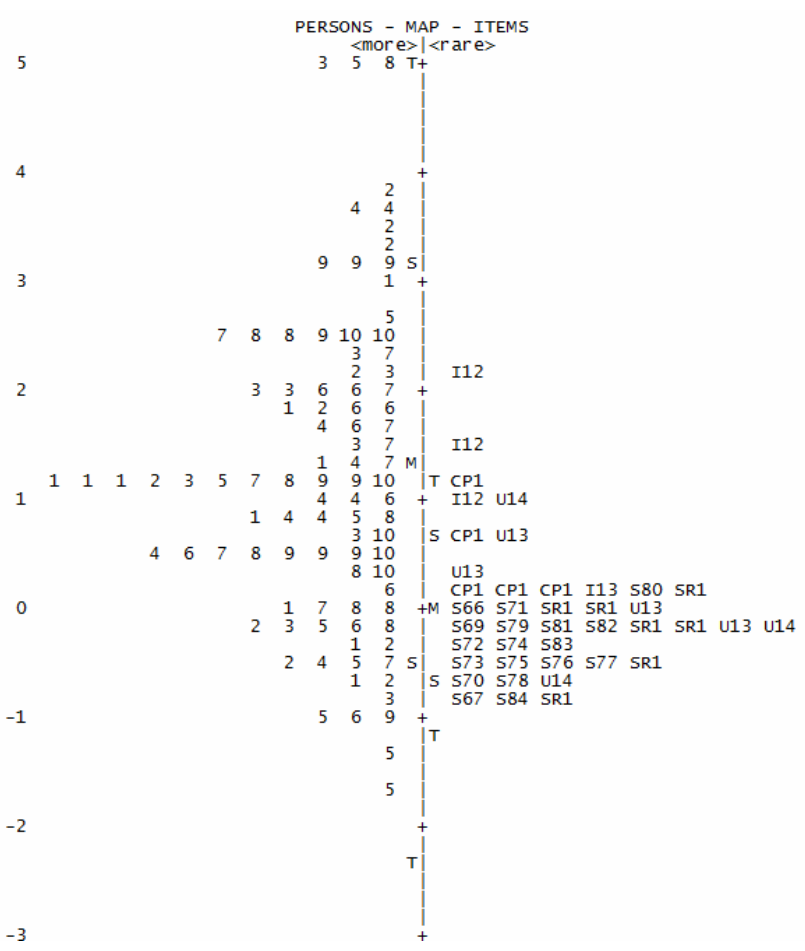

Figure 1. Hierarchy Map of Person and Items

their academic purposes. This finding shows a positive outcome and implying that using mobile application as a tool in learning can psychologically affect the learners.

Item no. 140 (U140) showed that the simple language used influences the students to adopt the SMS-Learning system. The result indicated the importance of language in mobile application. Learners prefer language that is simple, brief and short. It influences learners in understanding their studies.

Item no. 150 (SR150) supports the previous findings on usability and responsiveness. Whereby the learner's feels motivated when a simple language is used and the support that they acquire from the mobile application. Based on the finding, the learners are motivated to learn because they believed in using additional tools (mobile learning) to improve their study performance in their study. The result also showed that the learners are interested and happy in using mobile learning because the system assists them in learning process. In consistent with the previous researches done, show that motivational aspects is becoming an important task in research of multimedia based elearning tools [29] [30] while other researchers claim that the factor motivation is overestimated or may have even a negative impact on learning effectiveness due to a distraction effect [31].

The map also showed the result regarding items that students are not easily endorsed which are including items Interaction126, Interaction127 and Course Package123. The items represented "Availability of Resources" and "Openness to change" separately. Both items are included in the variable are group under the effectiveness of SMSLearning.

Item no. 126 (Interaction126) however shows disagreement among learners that occurs due to the weakness in the mobile learning system. The result shows that learners mostly disagreed with the variable due to the inconveniency to contact lack of open communication with 


\section{Motivation, Psychology And Language Effect On Mobile Learning IN UNIVERSITI SAINS MALAYSIA}

the instructor or lecturer or teaching aides or course mates. This problem arises due to the lack of this system whereby the learners can't communicate conveniently with the lecturer or course mate. This weakness should be taken into consideration in order to improve the mobile learning system as a successful tool in delivering information to the learners.

Item no. 127 (Interaction127) meanwhile listed as the least preferable item in this research. The result shows that learners insisted that it is very difficult to get response from the instructor on time. Based on is finding we can conclude that the system is not user- friendly because the current SMS-Learning used is a one-way communication. In contrary the system must support the response from one to many. This is consistent with the previous research which stated that most existing typical e-learning systems are tailored toward PC-based web access and are not customized to be used through mobile devices[32] [33]. In order to overcome these weaknesses learners therefore need to participate with the combination of e-learning method as well. As per said by a researcher M-learning is a form of e-learning that specifically employs wireless communication devices to deliver content and learning support [10].

Item no. 123 (Course Package) shows that course and technology used were not easy to navigate, inconsistent and not easy to be used. The current system used in this research is a preliminary system and there are weaknesses that need to be rectified. The feedbacks from the learners are useful information to improve the current system into a successful mobile application tool for academic purposes in the future.

\section{CONCLUSION}

In conclusion, this study showed that the usage of mobile application in the School of Distance Education, Universiti Sains Malaysia gave a positive impact on the student's psychology. The respondents felt supported as the lectures used mobile application as a tool in learning. It is also found that simple language used in the application positively influences the students to adopt the system in their learning environment. It also concluded that respondents felt motivated using the SMS-Learning system. Respondents were happy as they perceived that by using this additional learning tools (mobile learning), their learning processes and performances had improved. In reality there will be always new emerging technologies to improve the learning supporting tools. In short it can be concluded that the students positively responded to use mobile learning technologies as a modern process of learning now and in the future.

\section{ACKNOWLEDGMENT}

The authors would like to thank Universiti Sains Malaysia for the support under RU grant and USM Fellowship scheme.

\section{REFERENCES}

[1] Mark J. W. Lee and Anthony Chan (2007). Pervasive, lifestyleintegrated mobile learning for distance learners: an analysis and unexpected results from a podcasting study, Open Learning: The Journal of Open and Distance Learning, 22 (3), 201-218.

[2] Safie, N. (2004). The use of hort message services SMS as a supplementary learning tool in Open University Malaysia (OUM).
Annual Conference Associated of Asian Open University (AAOU) Shanghai, China.

[3] Quinn, C. (2000). MLearning: Mobile, Wireless and In-YourPocket Learning. Line Zine Magazine, http://www.linezine.com/ 2.1/features/cqmmwiyp.htm

[4] Trifonova, A. (2003). Mobile learning-review of the literature. (Technology Report No. DIT-03-009). University of Trento, Department of Information and Communication Technology.

[5] Wierzbicki Robert J. (2002). Emerging Issues in m-Learning WIERZBICKI.ORG - eLearning Solutions, Erlangen, Germany.

[6] MCMC (2009). Fact \& Figures (Statistics \& Record). Retrieved September 11, 2009 form http://www.skmm.gov.my/facts figures/ stats/index.asp

[7] Harris, P., Rettie, R. and Cheung, C.C. (2005). "Adoption and usage of m-commerce: A cross-cultural comparison of Hong Kong and the United Kingdom”, Journal of Electronic Commerce Research, 6(3), 210-224.

[8] Gilligan, R. and Heinzmann, P. (2004). "Exploring how cultural factors could potentially influence ICT use: An Analysis of European SMS and MMS use”, Cultural Difference Workgroup COST 269.

[9] DLSU-Manila (2003). Short messaging system. http://www.dasma.dlsu.edu.ph/wise/

[10] Brown, H.T. (2005). "Towards a model for MLearning”, International Journal on E-Learning, 4 (3), 299-315.

[11] Arbaugh, J.B. (2000). How classroom environment and student engagement affect learning in internet-based MBA courses, Business Communication Quarterly, 63 (4), pp. 9-26. doi:10.1177/ 108056990006300402

[12] Arbaugh, J.B. (2000). Virtual classroom characteristics and student satisfaction with internet-based MBA courses, Journal of Management Education, 24 (1), pp. 32-54. doi:10.1177/1052 56290002400104

[13] Spitzer, D. R. (1996). Motivation: The neglected factor in instructional design. Educational technology. 36(3), 45-49.

[14] Holzinger, A (2000) Basiswissen Multimedia Band 2: Lernen. Kognitive Grundlagen multimedialer Informationssysteme, Würzburg, Vogel

[15] Weidenmann, B (1997) Abbilder in Multimedia-Anwendungen, Information und Lernen mit Multimedia, L J Issing and P Klimsa. Weinheim, Psychologie Verlags Union

[16] Schulmeister, R (1996) Grundlagen hypermedialer Lernsysteme. Theorie, Didaktik, Design, Bonn, Addison-Wesley

[17] Hornik, S., Johnson R.D. and Wu Y. (2007). When technology doesn't support learning: conflicts between epistemological beliefs and technology support in virtual learning environments, Journal of Organizational and End User Computing 19 (2) 23-46.

[18] Nielsen, J. Usability Engineering. Morgan Kaufman Publisher, Academic Press, 1993.

[19] Kaikkonen, A., and Laarni, J. Designing for small display screens. In Proceedings of the 2nd Nordic Conference on HumanComputer Interaction. Aarhus, Denmark, New York: ACM Press, 19-23 October, 2002, 227- 230. doi:10.1145/572020.572052

[20] Ling, R and Helmerson, P. (2000). The adoption of mobile telephony among pre-adolescents and adolescents. Conference on the social consequences of mobile telephony, 16 June 2000, Oslo, Norway.

[21] Hard af Segerstad, Y. (2005). Language use in Swedish mobile text messaging. In R. Ling \& P. E. Pedersen (Eds.), Mobile Communications: Re-negotiation of the Social Sphere (pp. 313-333). London: Springer-Verlag.

[22] Ismail, I., Idrus, R.M. \& Baharum, H. (2010). Simplistic is the Ingredient for Mobile Learning. International Journal of Interactive Mobile Technologies (iJIM), 4 (3), 4-8

[23] Malaysian Communications and Multimedia Commission (2008). Hand phone users survey 2007. Retrieved August 25, 2009, from http://www.skmm.gov.my

[24] Sekaran, U. (2000). Research Method for Business: A skill Building Approach. John Wiley \& Sons. Inc.Singapore.

[25] Ren, W., Bradley, K.D., Lumpp J.K. (2008). Applying the Rasch Model to Evaluate an Implementation of the Kentucy Electronics 


\section{Motivation, Psychology And Language EfFect On Mobile Learning \\ IN UNIVERSITI SAINS MALAYSIA}

Educations Education Project. Journal of Science Education and Technology, 17(6), 618-625. doi:10.1007/s10956-008-9132-4

[26] Fox, C. (1999). An introduction to the partial credit model for developing nursing assessments. Journal of Nursing Education, 38(8), 340-346.

[27] Bond, T. G., \& Fox, C. M. (2001). Applying the Rasch model: Fundamental measurement in the human sciences. Mahwah, NJ: Erlbaum

[28] Harris, Jr. (2006). A study of Black University Students’ Perception of Marriage. Constructing and Evaluating measures: Applications of the Rasch measurement Model. Symposium presented at the Mid-Western educational Research Associationannual meeting, Columbus, OH, pp.19-24

[29] Astleitner, H (2000). Designing emotionally sound instruction: The FEASP-approach. Instructional Science 28, 169-198. doi:10.1023/A:1003893915778

[30] Brünken, R, S Steinbacher, W Schnotz \& D Leutner (2001) Mentale Modelle und Effekte der Präsentationsund Abrufkodalität beim Lernen mit Multimedia, Zeitschrift für pädagogische Psychologie 15(1).

[31] Kerres, M (2001) Multimediale und telemediale Lernumgebungen. Konzeption und Entwicklung,München/Wien, Oldenbourg

[32] Woukeu, A., Millard, E.D., Tao, F. and Davis, C.H. (2005), “Challenges for semantic grid based mobile learning”. Retrived August 18, 2009, from www.ubourgogne.fr/SITIS/05/download/ Proceedings/Files/f135.pdf
[33] Goh, T. and Kinshuk, D. (2006), "Getting ready for mobile learning - adaptation perspective”, Journal of Educational Multimedia and Hypermedia, 15(2), 175-198.

\section{AUTHORS}

Issham Ismail is with the School of Distance Education, Universiti Sains Malaysia, Minden, Pulau Pinang, 11800 Malaysia (e-mail: issham@usm.my)

Rozhan M. Idrus is with the School of Distance Education, Universiti Sains Malaysia, Minden, Pulau Pinang, 11800 Malaysia. He is specialized in Open and Distance Learning Interactive Technologies and e-Learning (e-mail: rozhan@usm.my).

Thenmolli Gunasegaran is a student in the School of Distance Education, Universiti Sains Malaysia, Minden, Pulau Pinang, 11800 Malaysia and currently doing her master in Management in Universiti Sains Malaysia. (email: gthenmolli@gmail.com).

This work was supported under RU Grant 1001/PJJAUH/817015 supported in part by the Universiti Sains Malaysia.

Submitted, July 26, 2010. Published as resubmitted by the authors on September 27, 2010. 